\title{
Impact of Silica Gel application under Different Irrigation Levels on Water Retention Characteristics and some Physical Properties of Clay Soil
}

\author{
F. N. Mahrous ${ }^{1}$ and S. H. AbdElghany ${ }^{2}$ \\ Soil Chem. \& Phys. Dept., Soil, Water and Environmental Institute, Agr. Res. Center, Giza, Egypt
}

Received: 30 Oct. 2019 / Accepted 15 Jan. 2020 / Publication date: 25 Jan. 2020

\begin{abstract}
A field experiment was conducted during two successive seasons (2017 and 2018) at Agricultural Research Center Station (ARC), Giza, Egypt. Clover was cultivated as an indicator crop to evaluate the residual effect of different rates of silica gel (hydrogel) as a soil inorganic amendment on rice crop yield and clover along with plant water relationships and soil physical properties. Four irrigation treatments, i.e. $60 \%, 70 \%, 80 \%$ and $90 \%$ of the applied water at recommended rate (RDWI) as well as four rates of soil amendment as silica gel $(\mathrm{Hg})\left(45,75,105\right.$ and 130) $\mathrm{kg} \cdot \mathrm{fd}^{-1}$ were added before cultivation. Mixing the soil by different rates of silica gel improved water soil retention parameter and their hydraulic conductivity $(\mathrm{Ks} \mathrm{cm} / \mathrm{hr})$ and bulk density $\left(\mathrm{BD} \mathrm{g} / \mathrm{cm}^{3}\right)$ The highest values were existed under the highest rate of silica gel $130 \mathrm{~kg} . \mathrm{fd}^{-1}$ at $80 \%$ RDWI, meanwhile the treatments of silica gel under $60 \%$ RDWI recorded the lowest values for soil water retention at the same level of (Hg). The residual effect of silica gel was non valuable and the addition of silica gel will be recommended every season to get the valuable improvement in soil water retention because of degradation of silica gel during the second season. The values of water holding capacity (WHC\%), field capacity (FC\%), wilting point $(\mathrm{WP} \%)$ and available water (AW\%) were improved as a result of silica gel addition to the soil compared to control during the first season. The corresponding relative increases were $35.13 \%, 49.50 \%, 33.93 \%$ and 33.31\% for (WHC\%), (FC\%), (WP\%) and (AW\%) respectively. Whereas the relative decreases for hydraulic conductivity $(\mathrm{Ks} \mathrm{cm} / \mathrm{hr})$ and bulk density $\left(\mathrm{BD} \mathrm{gm} / \mathrm{cm}^{3}\right)$ were $20.88 \%$ and $11.81 \%$ respectively. The maximum significant value was at $80 \%$ RDWI and 130 $\mathrm{kg} \cdot \mathrm{fd}^{-1} \mathrm{Hg}$ in the first season. These results indicated that the addition of silica gel should be added frequently every season to get sensing improvement for soil water parameters. The results of yield and crop water productivity (CWP) indicated that the best results for rice soil were existed at applied irrigation $80 \%$ of RDWI and $130 \mathrm{~kg} \cdot \mathrm{fd}^{-1}$ of $\mathrm{Hg}$ for the first season, and no longer effect at the second season during clover cultivation. Finally, it is concluded that, using $130 \mathrm{~kg} / \mathrm{fed}$ of silica gel as soil amendment are usable to save $20 \%$ of applied irrigation water for rice crop without reduction in yield. Also the additions of silica gel were recommended at every season due to the degradation of silica gel during the hydration cycle in between seasons which led to decrease the holding water ability of treated soils.
\end{abstract}

Keywords: Silica gel, Applied irrigation water, Water retention, Available water, water holding capacity, Wilting point, yield, crop water productivity.

\section{Introduction}

Rice (Oriza stiva L.) is a major staple food for much of the world's population and the largest consumer of water in the agricultural sector (Thakur et al., 2014). World food security remains largely dependent on irrigated lowland rice, which is the main source of rice supply (Yang and Zhang, (010). Fresh water for irrigation is becoming scarce because of population growth, increasing urban and industrial development, and the decreasing availability resulting from pollution and resource depletion (Thakur et al., 2011). Egyptian Ministry of Irrigation and Water Resources (2018), has announced that the government is reducing the area of land available for rice cultivation by more than 50 per cent. Instead of 1.7 million feddans, only around 700,000 feddans will be cultivated this year (one feddan is 1.038 acres). The decision, taken to rationalize water consumption, will be applied from May to September 2018. The use of superabsorbent polymers is one of the solutions to increase the water use efficiency in agriculture, leading to the increased quality of crop yield (Sharifan et al., 2013). Superabsorbent polymers are hydrophilic networks absorbing a large volume of water (200-

Corresponding Author: F. N. Mahrous, Soil Chem. \& Phys. Dept., Soil, Water and Environmental Institute, Agr. Res. Center, Giza, Egypt 
$500 \mathrm{ml}$ per gram dry weight) (Zohurian and Kabiri, 2008). For instance, zeolite is one of the mineral soil amenders which could be used in order to improve soil physical and chemical conditions and increase soil water holding capacity (Abedi- Koupai et al., 2008). This substance is able to absorb water in the soil to saturation point and hold it for a long time within its network as the water in the network could be absorbed by plant gradually (Polite et al., 2004). In this way, with needless to reirrigation, soil moisture remains for a long time (Widiastuti et al., 2008). Stockosorb is a polyacrylamide polymer and because of its cross-linked structure, it has a large water absorption capability (Chirino et al., 2011) so that one $\mathrm{kg}$ of this superabsorbent can absorb 250 liter of water (Evonik Industries, 2014). Stockosorb is resistant to the temperature fluctuations in soil and remains in the soil for a longer time as compared to other super-absorbents (Luo and Polle, 2009). Several studies had been performed on the application of super-absorbents (Li et al., 2004), physical and chemical properties of them (Thakhur et al., 2014), and their effects on soil and plants (Wu et al., 2012). Researchers reported that hydrophilic polymers led to increase water holding capacity in sandy soils and reduce water losses through leaching (Ekebafe et al., 2011). Nazarli et al. (2010) showed that superabsorbent polymers led to water retention increase in the soil, reducing the irrigation to $50 \%$. Wu et al. (2008) studied the relationship between applying super-absorbents and plant available water, and showed that using these polymers, on average, $10.68 \%$ higher water is kept in the soil as compared with control. Result of another research has shown that stockosorb superabsorbent (type of hydrogel) enhanced soil permeability and water use efficiency (Montazer, 2008). Bal et al. (2010) applied different types of super-absorbents in a sandy soil and found that it increased soil moisture content while soil bulk density and EC were decreased. Zangooei et al. (2013) reported the positive and significant effect of using stockosorb superabsorbent on the growth indices of Haloxylon persicum including height, shoot fresh and dry weight, root fresh and dry weight and root length. Abrisham (2015) showed that all three superabsorbent materials such as stockosorb, anionic polyelectrolyte and mineral zeolite (clinoptilolite) had positive effects on the chemical, physical and hydrological characteristics of the soil and vegetative properties in drought conditions. According to the joint project of FAO and Forests, Range and Watershed Organization of Iran, Atriplex species have been introduced for range improvement in arid regions so that the cultivation of this species in desert regions of Iran has been recommended (Rahimzadeh et al., 2011). On the other hand, water resources are the most important limiting factor in arid and desert regions (Chen et al., 2014). Given limited water resources in Iran and the dominant share of agriculture in the use of these resources, conservation of water and the use of management techniques to enhance water use efficiency are of utmost importance (Sharifan et al., 2013). Yousefian et al. (2018) showed that superabsorbent had a significant effect on EC, $\mathrm{pH}$, field capacity, available water, bulk density, porosity, $\mathrm{K}$. Also, the result of economical investigation of stockosorb and zeolite showed that using $10 \%$ of zeolite weight, $15 \%$ of zeolite weight and $0.1 \%$ of stockosorb weight with normal irrigation is economical. Aly et al. (2016) studied the effect of irrigation stress and different rates of hydrogel polyvinylalcohol (PVA) as a soil amendment on peanut crop yield and macronutrients total contents along with some plant water relationships. Their results showed that water use efficiency (WUE) was significant. The values of WUE could be increased either by increasing crop yield or decreasing evapotranspiration. The highest values of WUE were gained using irrigation level of $50 \%$ available soil moisture (ASM) irrigation treatment followed by 25 and $75 \%$ ASM and the differences were significant. The relationship between water use efficiency (WUE) and seeds yield along with concentration of PVA was significantly positive linear correlation in successive two cultivated seasons. Alireza et al. (2016) investigated the effects of superabsorbent polymer

(SAP) and irrigation management on seed and essential oil yields of Cumin. SAP application $\left(30 \mathrm{~kg} \cdot \mathrm{ha}^{-1}\right)$ along with three times irrigation at sowing, flowering and seed filling stages increased the amounts of seed and essential oil yields by 2.79 and 3.05 times, compared to control. Positive effects of SAP were related to enhancement of soil water holding capacity (120 gr irrigation water per gr SAP), leaf area duration (one week) and subsequently grain filling period. Ekebafe et al. (2011) indicated that the use of polymer in agriculture is gaining popularity in science, particularly in the field of polymer chemistry. It has provided solutions to the problems of the present day agriculture which is to maximize land and water productivity without threatening the environment and the natural resources. Superabsorbent polymer hydrogel potentially influence soil permeability, density, structure, texture, evaporation and infiltration rates of water through the soils. Liliana et al. (2017) examined the 
natural fiber swelling properties to use as a hydrogel, since they give to material an elasticity and rigidity properties to absorb water. A hydrogel efficiency applied to soil, is measured throughout properties as swell ability, mechanical strength, and soil water retention. It was concluded that hydrogels, are an alternative to the current needs for the agricultural sector.

Krzysztof et al. (2018) determined the application of superabsorbent polymer SAP on soil bulk density and soil water absorption by adding SAP to soil. The obtained results showed that the effectiveness of SAP application for water retained (absorbed) by soil in comparison to the control sample. Also the obtained results pointed to the necessity of reconsidering the different ways of applying SAPs to soil due to geo-composites and minimize the influence of the water absorption process. The aim of the current research was to compare the recommended applied irrigation water with the fractions of this irrigation rate to save water supply as the result of hydrogel application as well as the suitable rate of using hydrogel. The main objective of this experiment was to study the effect of silica gel as soil amendment inorganic, cheep and locally hydrogel under different levels of irrigation on some soil physical properties, and their impact on the yield of both rice and clover crops.

\section{Materials and Methods}

A field experiment was carried out at Experimental Station of Agriculture Research Center (ARC) during two successive seasons. The ARC station is located at $30^{\circ} 21.5^{\prime} 52^{\prime \prime} \mathrm{N}$ latitude and $31.2^{\circ}$ 9.6' 345" E longitude. Egyptian rice (Oryza sativa L); namely Sakha 108 and Egyptian clover berseem (Trifollium alexandrinum L.) ; namely Giza 6 as an indicator crop to evaluate the residual effect of silica gel at different rates. Some physical and chemical characteristics of the studied soil and the chemical analysis of irrigation water are shown in Table (1), while physical and chemical characteristics of the used silica gel are shown in (2). Silica gel is an gelatinous material the main constituent of it is silicic acid $\left(\mathrm{H}_{2} \mathrm{SiO}_{3}\right)$ and it is very week acid, swell a large amount of water relative to dry mater as $(\mathrm{SiO} 2)$. The applied treatments of cultivation were conducted under the recommendations of ARC (2013) and FAO (2005). Total irrigation water for rice and clover per season were $(6500 \text { and } 2750)^{3}$. $\mathrm{fd}^{-1}$, respectively. The experiment was designed in a split plot design with three replicates under furrow irrigation the main plot was silica gel treatments whereas the sub plot was the irrigation doses. The treatments of irrigation water were applied in the different doses $60 \%, 70 \%, 80 \%$ and $90 \%$ RDWI from recommended dose, meanwhile silica gel doses $(45,75,105$ and 130$) \mathrm{Kg}_{\text {. fd }}{ }^{-1}$, which were calculated as its active material of $\mathrm{SiO}_{2}$. All treatments were illustrated in table (3). Each treatment was replicated three times and in split plot design. The yield per plot was determined then the yields were calculated as feddan production of grains for rice and fresh forage yield as the summation weight of the six cuts for Egyptian clover. Samples of clover were harvested for dry matter from each plot by hand, weighed for fresh weight, then dried at $60^{\circ} \mathrm{C}$ for 48 hours. Soil samples were taken from all the studied treatments to determine some soil characteristics and ability of water retention. The tested soil and irrigation water were subjected to the following analyses: Spectrophotometric method for the determination of available phosphorus determined according to Murphy and Riley (1962) as modified by Watanabe and Olsen (1965). Evaluating soluble anions and cations were determined according to Page (1982). The electrical conductivity EC (ds/m), pH, sodium and potassium were determined as described by Jackson (1973). Available micronutrients were measured by plasma spectroscopy according to Cottenie et al., (1982). Particle size distribution was measured by pipette method Gee and Bauder (1986). Organic matter and calcium carbonate were evaluating according Black (1982). Determination of carbonate, bicarbonate and chlorides were according USSL (1969). The soil moisture characteristics curve for each treatment was prepared by using the pressure plate apparatus (Klute, 1986). The pf curve points were selected at suction pressures of $-0.1,-0.33,-0.66,-1.0$ and $-15.0 \mathrm{bar}$, which are corresponding to $\mathrm{pF} 2.0,2.53,2.82,3.0$ and 4.2 , then the point of $\mathrm{pf}=7$ was estimated by drying the samples overnight at $105^{\circ} \mathrm{c}$. Water content at each pressure was calculated from the volume of outflow between pressure steps, the final water content, and the weight of oven-dried soil. Furthermore, the available water $\left(\mathrm{cm}^{3} / \mathrm{cm}^{3}\right)$ was calculated by the subtraction of water content at Field capacity (FC) and permanent wilting point (PWP). 
The water percentage $\theta \mathrm{v}(\%)$ at each pressure level was volumetrically calculated as well as the mass water percentage $\theta \mathrm{m}(\%)$.

-The water content at $0.001 \mathrm{bar}=(\theta \mathrm{m}) 0.001=$ Water Holding Capacity $(\mathrm{WHC})$ of soil.

- The water content at $0.1 \mathrm{bar}=(\theta \mathrm{m}) 0.1=$ Field capacity $(\mathrm{FC})$ of soil.

- The water content at $15 \mathrm{bar}=(\theta \mathrm{m}) 15=$ Wilting Point WP.

- The volume water percentage $\theta \mathrm{v}(\%)$ at each pressure level was calculated as per cent value.

Saturated hydraulic conductivity (Ks): It was determined by head method, of Klute,( 1986).

The hydraulic conductivity of the soil (Ks) was calculated according to the equation:

$$
\mathrm{K}_{\mathrm{s}}=\mathrm{QL} / \mathrm{HAT}
$$

Where Ks $(\mathrm{cm} / \mathrm{hr})$ : the saturated hydraulic conductivity, Q: the volume of the collecting water peculation $(\mathrm{mL}), \mathrm{L}$ : soil column height inside the core $(\mathrm{cm}), \mathrm{H}$ : the total head $(\mathrm{cm}), \mathrm{A}$ : the cross sectional area of the core $\left(\mathrm{cm}^{2}\right)$, T: time needed for collecting percolates $(\mathrm{Q})$.

Bulk density (BD): it was estimated according to the core method (Black, 1982);

Bulk Density $\left(\mathrm{g} / \mathrm{cm}^{3}\right)=$ [oven dried weight of soil column/ volume of soil column ]

Crop water productivity (CWP): Irrigation water productivity is commonly calculated according to Michael (1978) as fellow:

$$
\text { CWP }\left(\mathrm{kg} / \mathrm{m}^{3}\right)=\quad \begin{gathered}
\text { Crop yield }(\mathrm{kg}) \\
\text { Water consumed }\left(\mathrm{m}^{3}\right)
\end{gathered}
$$

Silica gel preparation: An aqueous solution of sodium silicate is acidified by diluted solution of citric acid to produce gelatinous slurry that is washed to get rid of excess sodium ions, and then produce colorless silica gel (Greenwood and Earnshaw 1997).

Table 1: Some physical and chemical characteristics of the experimental soil and the used irrigation

\begin{tabular}{|c|c|c|c|}
\hline \multicolumn{2}{|l|}{$\begin{array}{r}\text { Soil characteristics } \\
\end{array}$} & \multicolumn{2}{|c|}{ Irrigation water characteristics } \\
\hline Chemical properties & & $\mathrm{pH}$ (Irrigation water) & 7.23 \\
\hline pH (suspension 1:2.5) & 7.63 & $\mathrm{EC} \mathrm{dS} / \mathrm{m}$ & 0.93 \\
\hline EC $\mathrm{dS} / \mathrm{m}$ (saturation soil paste extract) & 2.10 & Sodium adsorption ration (SAR) & 3.20 \\
\hline Organic matter $\%$ & 1.10 & Adj. SAR & 7.68 \\
\hline Particle size distribution \% & & Soluble ions (mmole/l & \\
\hline Coarse sand & 10.15 & $\mathrm{Ca}^{++}$ & 2.39 \\
\hline Fine sand & 16.85 & $\mathrm{Mg}^{++}$ & 1.84 \\
\hline Silt & 34.50 & $\mathrm{Na}^{+}$ & 4.64 \\
\hline Clay & 38.50 & $\mathrm{~K}^{+}$ & 0.62 \\
\hline Texture class & Clay loam & $\mathrm{CO}_{3}^{--}$ & 0.00 \\
\hline Soluble cations and anions (meq/l) & & $\mathrm{HCO}_{3}{ }^{-}$ & 5.30 \\
\hline $\mathrm{Ca}^{++}$ & $5 . .01$ & $\mathrm{Cl}^{-}$ & 3.65 \\
\hline $\mathrm{Mg}^{++}$ & 4.42 & $\mathrm{SO}_{4}^{--}$ & 0.54 \\
\hline $\mathrm{Na}^{+}$ & 11.80 & Water content of some heavy $n$ & \\
\hline $\mathrm{K}^{+}$ & 0.40 & & \\
\hline $\mathrm{CO}_{3}^{--}$ & 0.00 & $\mathrm{Zn}$ & 0.907 \\
\hline $\mathrm{HCO}_{3}^{-}$ & 1.00 & $\mathrm{Mn}$ & 0.346 \\
\hline $\mathrm{Cl}^{-}$ & 9.00 & $\mathrm{Fe}$ & 0.711 \\
\hline $\mathrm{SO}_{4}^{--}$ & 11.63 & $\mathrm{Cu}$ & 0.185 \\
\hline \multicolumn{4}{|l|}{ Available nutrients (mg/kg) } \\
\hline $\mathrm{N}$ & 85 & $\mathrm{Cd}$ & 0.019 \\
\hline $\mathrm{P}$ & 15 & $\mathrm{Ni}$ & 0.087 \\
\hline \multirow[t]{2}{*}{ K } & 230 & $\mathrm{Co}$ & 0.036 \\
\hline & & $\mathrm{Pb}$ & 0.472 \\
\hline
\end{tabular}
water chemical analysis 
Table 2: The important characteristics of used silica gel

\begin{tabular}{lc}
\hline Characteristic & Description \\
\hline $\mathbf{p H}$ & $6.5-7.0$ \\
$\mathbf{E c}(\mathbf{d S} / \mathbf{m})$ & 0.98 \\
Density & $1.11 \mathrm{~g} . \mathrm{cm}^{-3}$ \\
Appearance & Semitransparent gel \\
Field capacity & $58.50 \%$ \\
Wilting point & $3.20 \%$ \\
Available water & $55.30 \%$ \\
Total porosity & $79 \%$ \\
Swelling capacity relative to SiO2 & $350 \mathrm{~g} / \mathrm{g}$ \\
\%SiO2 & $0.29 \%$ \\
Hydraulic conductivity $(\mathbf{K s})$ & $1.21 \mathrm{~cm} / \mathrm{hr}$ \\
\hline
\end{tabular}

Table 3: Treatments of silica gel and irrigation water.

\begin{tabular}{|c|c|c|c|}
\hline & & Rate of applied silica gel and irrigation water & Symbol \\
\hline \multicolumn{2}{|c|}{ Control (complete RDWI*) } & Without silica gel treatment & $\mathrm{T}_{0}$ \\
\hline \multirow{16}{*}{$\begin{array}{l}\text { Water } \\
\text { irrigation } \\
\text { rates }\end{array}$} & \multirow{4}{*}{ (60\%RDWI) } & Rate of $45 \mathrm{Kg} \mathrm{fd}^{-1}$ of applied silica gel $(45 \mathrm{Hg})$. & $\mathrm{T}_{1}$ \\
\hline & & Rate of $75 \mathrm{Kg} \mathrm{fd}^{-1}$ of applied silica gel $(75 \mathrm{Hg})$ & $\mathrm{T}_{2}$ \\
\hline & & Rate of $105 \mathrm{Kg}$. $\mathrm{fd}^{-1}$ of applied silica gel $(105 \mathrm{Hg})$. & $\mathrm{T}_{3}$ \\
\hline & & Rate of $130 \mathrm{Kg} . \mathrm{fd}^{-1}$ of applied silica gel $(130 \mathrm{Hg})$. & $\mathrm{T}_{4}$ \\
\hline & \multirow{4}{*}{ (70\%RDWI) } & Rate of $45 \mathrm{Kg} . \mathrm{fd}^{-1}$ of applied silica gel $(45 \mathrm{Hg})$ & $\mathrm{T}_{5}$ \\
\hline & & Rate of $75 \mathrm{Kg}$. $\mathrm{fd}^{-1}$ of applied silica gel $(75 \mathrm{Hg})$ & $\mathrm{T}_{6}$ \\
\hline & & Rate of $105 \mathrm{Kg} \mathrm{fd}^{-1}$ of applied silica gel $(105 \mathrm{Hg})$. & $\mathrm{T}_{7}$ \\
\hline & & Rate of $130 \mathrm{Kg}$. $\mathrm{fd}^{-1}$ of applied silica gel $(130 \mathrm{Hg})$. & $\mathrm{T}_{8}$ \\
\hline & \multirow{4}{*}{$(80 \%$ RDWI $)$} & Rate of $45 \mathrm{Kg} . \mathrm{fd}^{-1}$ of applied silica gel $(45 \mathrm{Hg})$ & $\mathrm{T}_{9}$ \\
\hline & & Rate of $75 \mathrm{Kg} . \mathrm{fd}^{-1}$ of applied silica gel $(75 \mathrm{Hg})$ & $\mathrm{T}_{10}$ \\
\hline & & Rate of $105 \mathrm{Kg}$. $\mathrm{fd}^{-1}$ of applied silica gel $(105 \mathrm{Hg})$. & $\mathrm{T}_{11}$ \\
\hline & & Rate of $130 \mathrm{Kg} . \mathrm{fd}^{-1}$ of applied silica gel $(130 \mathrm{Hg})$. & $\mathrm{T}_{12}$ \\
\hline & \multirow{4}{*}{$(90 \%$ RDWI) } & Rate of $45 \mathrm{Kg} . \mathrm{fd}^{-1}$ of applied silica gel $(45 \mathrm{Hg})$ & $\mathrm{T}_{13}$ \\
\hline & & Rate of $75 \mathrm{Kg}$. $\mathrm{fd}^{-1}$ of applied silica gel $(75 \mathrm{Hg})$ & $\mathrm{T}_{14}$ \\
\hline & & Rate of $105 \mathrm{Kg} \mathrm{fd}^{-1}$ of applied silica gel $(105 \mathrm{Hg})$. & $\mathrm{T}_{15}$ \\
\hline & & Rate of $130 \mathrm{Kg} . \mathrm{fd}^{-1}$ of applied silica gel $(130 \mathrm{Hg})$. & $\mathrm{T}_{16}$ \\
\hline
\end{tabular}

*Recommended dose of water irrigation

\section{Statistical analysis:}

Analysis of Variance (ANOVA) of the obtained data was performed using a split plot design procedure in SPSS version 18. The statistical differences among treatments means across traits were conducted using LSD test. Mean differences were considered significant at $\mathrm{p}=0.05$.

\section{Results and Discussion}

\section{1- Effect of silica gel treatments at different irrigation levels on soil water retention curves: -}

The data illustrated in Table (4) and Fig. $(1,2)$ revealed that mixing the clay soil with the silica gel showed high pronounced effect on its values of water holding capacity (WHC\%). Addition of silica gel increased significantly soil water content $\left(\theta_{\mathrm{v}}\right)$ under different pressure values. The highest values of (WHC \%) recorded at the $130 \mathrm{~kg} /$ fed application rate of silica gel and they were $76.24 \%$ and $62.93 \%$ for the first and second seasons respectively. While, untreated soil observed with the lowest values $56.42 \%$ and $56.11 \%$ for the two seasons at different irrigation levels respectively. With respect to the untreated soil, addition of silica gel increased significantly (WHC \%) to 35.13\% and $12.15 \%$ the first and second seasons respectively. Concerning the effect of irrigation levels on (WHC\%) under different rats of silica gel it was found that there no significant differences between the irrigation levels of $80 \%$ RDWI and $90 \%$ RDWI in first season but the $90 \%$ RDWI recorded the highest 
(WHC\%) during the second season. Generally mixing the clay soil with different rates of silica gel had significant differences at first seasons in contrast during the second season.

With respect to field capacity (FC \%) the mentioned data in Table (5) and illustrated in Fig. $(1,2)$ declared that the increasing in silica gel treatments increased significantly (FC\%) in the first season and was no effect in the second season at all of irrigation levels. The $130 \mathrm{~kg} /$ fed silica gel treatment recorded the highest $(\mathrm{FC} \%)$ value $(49.5 \%)$ at the first season compared to control value $(37.81 \%)$ whereas the relative increasing value compared to untreated soil was (30.91\%). Furthermore the $80 \%$ RDWI and 90\% RDWI irrigation levels recorded the highest values in (FC \%) at all different rates of silica gel addition. Furthermore there were insignificant differences between both the irrigation levels of $80 \%$ RDWI and $90 \%$ RDWI in first season affecting by silica gel addition.

Concerning the wilting point (WP \%), the data presented in Table (6) and Fig.(1,2) clear that there were significant differences in (WP\%) due to mixing the silica gel with the investigated soil through the first season. The increments in silica gel doses lead to elevation in (WP\%) values, the highest (WP\%) value recorded for the $130 \mathrm{~kg} /$ fed silica gel treatment which was $24.39 \%$ compared to control $(18.21 \%)$. The relative increasing in (WP \%) was 33.93\% during the first season at all irrigation levels. On the other hand, the addition of silica gel to soil with different amounts insignificantly affect the (WP \%) in the second season. Also insignificant differences were observed between both the $80 \%$ RDWI and $90 \%$ RDWI levels with the increase in the concentration of silica gel in soil. The available water(AW\%) is the difference between field capacity which is the maximum amount of water that the soil can hold and wilting point where the plant became no longer extract water from the soil.

Table 4: Effect of Irrigation levels and silica gel treatments on water holding capacity (WHC \%) during the first season and their residual effects through the second season.

\begin{tabular}{|c|c|c|c|c|c|c|c|c|c|c|}
\hline \multirow{2}{*}{$\begin{array}{c}\text { Silica gel } \\
\text { treatments } \\
\text { Kg/fed }\end{array}$} & \multicolumn{4}{|c|}{$\begin{array}{l}\text { First season } \\
\text { Irrigation treatments }\end{array}$} & \multirow[b]{2}{*}{ Mean } & \multicolumn{5}{|c|}{$\begin{array}{c}\text { Second season } \\
\text { Irrigation treatments }\end{array}$} \\
\hline & $\begin{array}{c}60 \% \\
\text { RDWI }\end{array}$ & $\begin{array}{c}70 \% \\
\text { RDWI }\end{array}$ & $\begin{array}{c}80 \% \\
\text { RDWI }\end{array}$ & $\begin{array}{c}90 \% \\
\text { RDWI }\end{array}$ & & $\begin{array}{c}60 \% \\
\text { RDWI }\end{array}$ & $\begin{array}{c}70 \% \\
\text { RDWI }\end{array}$ & $\begin{array}{c}\mathbf{8 0} \% \\
\text { RDWI }\end{array}$ & $\begin{array}{c}90 \% \\
\text { RDWI }\end{array}$ & Mean \\
\hline $45 \mathrm{Hg}$ & 60.22 & 66.10 & 77.22 & 77.70 & $70.31^{\mathrm{c}}$ & 58.02 & 60.42 & 60.22 & 62.74 & $60.35^{\mathrm{a}}$ \\
\hline 75 HG & 61.04 & 67.62 & 78.42 & 79.56 & $71.66^{\mathrm{c}}$ & 58.70 & 61.14 & 60.94 & 63.50 & $61.07^{\mathrm{a}}$ \\
\hline $105 \mathrm{Hg}$ & 62.02 & 68.50 & 80.66 & 82.02 & $73.30^{\mathrm{b}}$ & 59.22 & 61.69 & 62.02 & 64.63 & $61.89^{\mathrm{a}}$ \\
\hline $130 \mathrm{HG}$ & 65.22 & 70.02 & 84.88 & 84.82 & $76.24^{\mathrm{a}}$ & 59.70 & 62.19 & 63.56 & 66.25 & $62.93^{\mathrm{a}}$ \\
\hline Mean & $62.13^{c}$ & $68.06^{\mathrm{b}}$ & $80.30^{\mathrm{a}}$ & $81.03^{\mathrm{a}}$ & & $58.91^{\mathrm{d}}$ & $61.36^{\mathrm{c}}$ & $61.69^{b}$ & $64.28^{\mathrm{a}}$ & \\
\hline & \multicolumn{5}{|c|}{$\mathrm{WHC} \%$ for control $=55.42$} & \multicolumn{5}{|c|}{$\mathrm{WHC} \%$ for control $=56.11$} \\
\hline $\begin{array}{l}\text { Silica gel } \\
\text { treatment(h) }\end{array}$ & $\begin{array}{l}\mathbf{L S D}_{(\mathbf{0 . 0 5})} \\
2.88\end{array}$ & & & & & $\begin{array}{l}\mathbf{L S D}_{(\mathbf{0 . 0 5})} \\
2.51\end{array}$ & & & & \\
\hline $\begin{array}{l}\text { Irrigation } \\
\text { levels(i) }\end{array}$ & 3.80 & & & & & $\mathrm{~ns}$ & & & & \\
\hline hXi & 5.34 & & & & & ns & & & & \\
\hline
\end{tabular}

Table 5: Effect of Irrigation levels and silica gel treatments on field capacity (FC\%) during the first season and their residual effects through the second season.

\begin{tabular}{|c|c|c|c|c|c|c|c|c|c|c|}
\hline \multicolumn{6}{|c|}{ First season } & \multicolumn{5}{|c|}{ Second season } \\
\hline Silica gel & \multicolumn{4}{|c|}{ Irrigation treatments } & & \multicolumn{5}{|c|}{ Irrigation treatments } \\
\hline $\begin{array}{c}\text { treatments } \\
\mathrm{Kg} / \mathrm{fed}\end{array}$ & $\begin{array}{c}60 \% \\
\text { RDWI }\end{array}$ & $\begin{array}{c}70 \% \\
\text { RDWI }\end{array}$ & $\begin{array}{c}80 \% \\
\text { RDWI }\end{array}$ & $\begin{array}{c}90 \% \\
\text { RDWI }\end{array}$ & Mean & $\begin{array}{c}60 \% \\
\text { RDWI }\end{array}$ & $\begin{array}{c}70 \% \\
\text { RDWI }\end{array}$ & $\begin{array}{c}80 \% \\
\text { RDWI }\end{array}$ & $\begin{array}{c}90 \% \\
\text { RDWI }\end{array}$ & Mean \\
\hline 75 HG & 38.99 & 43.01 & 49.00 & 49.59 & $45.15^{\mathrm{c}}$ & 36.89 & 37.21 & 37.27 & 37.50 & $37.22^{\mathrm{a}}$ \\
\hline $105 \mathrm{Hg}$ & 39.00 & 44.56 & 53.24 & 54.00 & $47.70^{\mathrm{b}}$ & 37.00 & 37.25 & 37.33 & 37.66 & $37.31^{\mathrm{a}}$ \\
\hline \multicolumn{11}{|c|}{$\mathrm{FC} \%$ for control $=37.81$} \\
\hline & $\mathbf{L S D}_{(0.05)}$ & & & & & $\operatorname{LSD}_{(0.05)}$ & & & & \\
\hline $\begin{array}{l}\text { Silica gel } \\
\text { treatment(h) }\end{array}$ & 1.72 & & & & & ns & & & & \\
\hline $\begin{array}{l}\text { Irrigation } \\
\text { levels(i) }\end{array}$ & 1.67 & & & & & ns & & & & \\
\hline
\end{tabular}



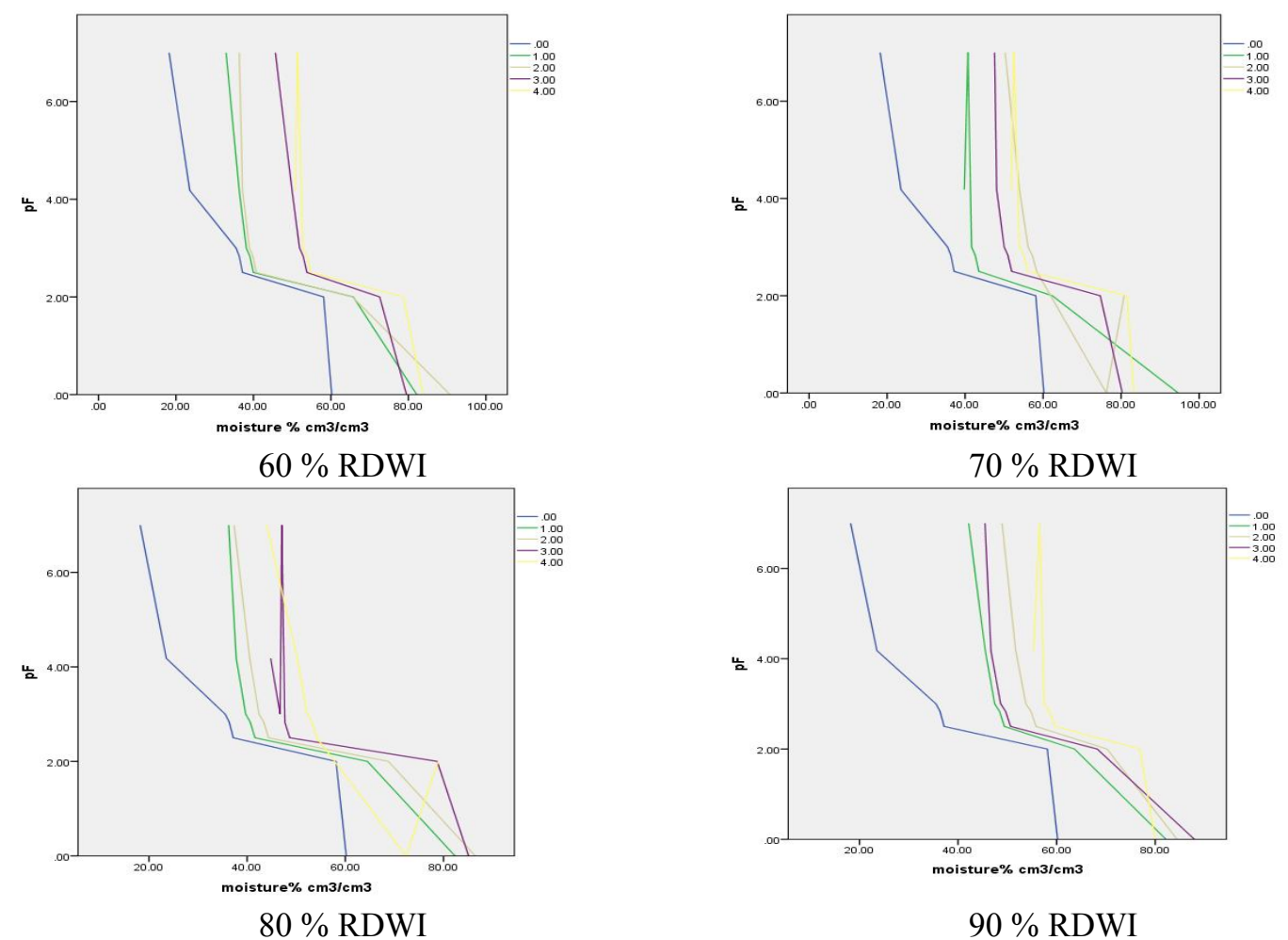

Fig. 1: The water retention curves of soil mixed by various treatments of silica gel during the first season.

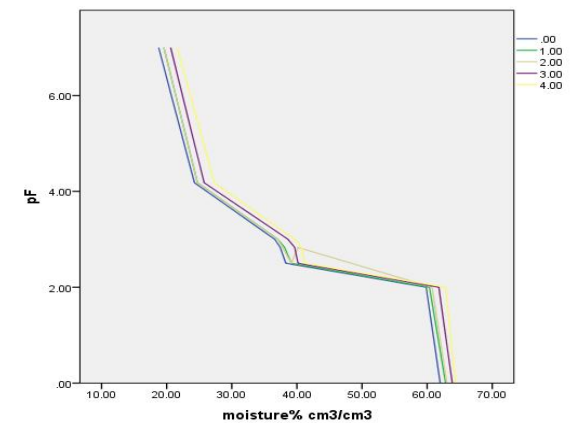

$60 \%$ RDWI

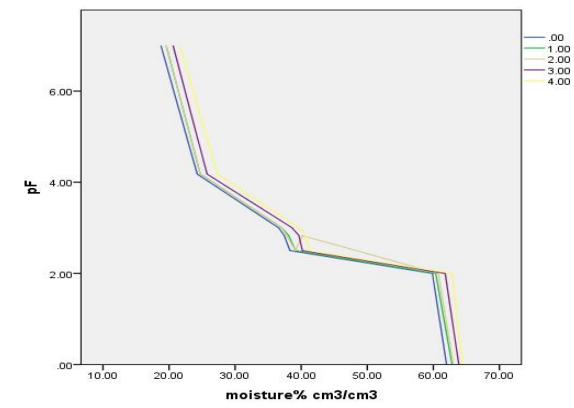

$80 \%$ RDWI

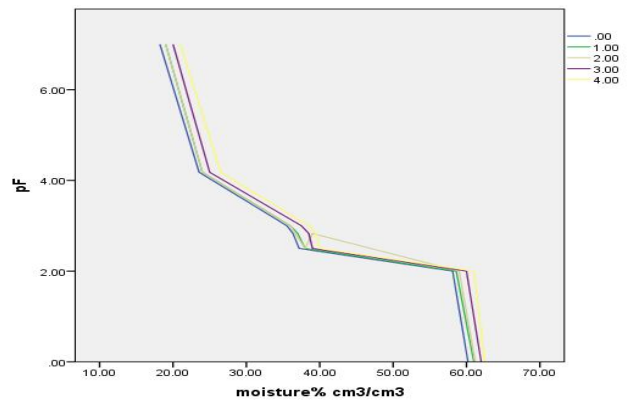

$70 \%$ RDWI

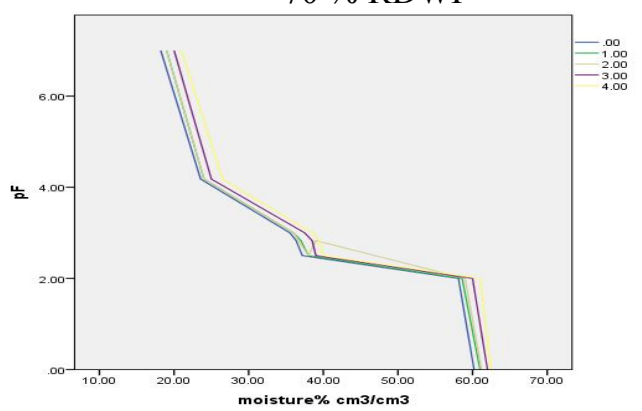

$90 \%$ RDWI

Fig. 2: The water retention curves of soil mixed by various treatments of silica gel during the second season.

0 - Control $-45 \mathrm{~kg} /$ fed of silica gel $12---75 \mathrm{~kg} /$ fed of silica gel $\quad 3---105 \mathrm{~kg} / \mathrm{fed}$ of silica gel

$4---130 \mathrm{~kg} / \mathrm{fed}$ of silica gel 
Table 6: Effect of Irrigation levels and silica gel treatments on wilting point (WP\%) during the first season and their residual effects through the second season.

\begin{tabular}{|c|c|c|c|c|c|c|c|c|c|c|}
\hline \multicolumn{6}{|c|}{ First season } & \multicolumn{5}{|c|}{$\begin{array}{c}\text { Second season } \\
\text { Irrigation treatments }\end{array}$} \\
\hline $\begin{array}{l}\text { treatments } \\
\mathrm{Kg} / \text { fed }\end{array}$ & $\begin{array}{c}60 \% \\
\text { RDWI }\end{array}$ & $\begin{array}{c}70 \% \\
\text { RDWI }\end{array}$ & $\begin{array}{c}80 \% \\
\text { RDWI }\end{array}$ & $\begin{array}{c}90 \% \\
\text { RDWI }\end{array}$ & Mean & $\begin{array}{c}60 \% \\
\text { RDWI }\end{array}$ & $\begin{array}{c}70 \% \\
\text { RDWI }\end{array}$ & $\begin{array}{c}80 \% \\
\text { RDWI }\end{array}$ & $\begin{array}{c}90 \% \\
\text { RDWI }\end{array}$ & Mean \\
\hline $75 \mathrm{HG}$ & 20.45 & 22.32 & 25.01 & 25.53 & $23.33^{\mathrm{b}}$ & 18.33 & 18.55 & 18.70 & 18.49 & $18.52^{\mathrm{a}}$ \\
\hline $105 \mathrm{Hg}$ & 21.11 & 23.05 & 26.14 & 26.70 & $24.25^{\mathrm{ab}}$ & 18.33 & 18.65 & 18.73 & 18.59 & $18.58^{\mathrm{a}}$ \\
\hline \multirow{2}{*}{ Mean } & \multicolumn{5}{|c|}{$\mathrm{WP} \%$ for control $=18.21$} & \multicolumn{5}{|c|}{$\mathrm{WP} \%$ for control $=18.71$} \\
\hline & $\operatorname{LSD}_{(0.05)}$ & & & & & $\operatorname{LSD}_{(0.05)}$ & & & & \\
\hline $\begin{array}{l}\text { Silica gel } \\
\text { treatment(h) }\end{array}$ & 2.41 & & & & & ns & & & & \\
\hline $\begin{array}{l}\text { Irrigation } \\
\text { levels(i) }\end{array}$ & 0.65 & & & & & ns & & & & \\
\hline
\end{tabular}

There were improving to soil available water due to apply different rats of silica gel to the clay soil, the $130 \mathrm{~kg} /$ fed of silica gel treatment was the highest (AW\%) value $24.57 \%$ as shown in Table (8) and Fig. $(1,2)$ whereas the relative increase was $33.31 \%$ compared to the untreated soil $(18.43 \%)$ at all irrigation levels during the first season as shown in Table (7) and Fig.(1,2). Moreover the 80\% RDWI and $90 \%$ RDWI levels recorded the highest (AW \%) with no significant differences between them. The obtained results from the interaction between different silica gel doses and irrigation levels showed that there is no significant effect on the improving of (AW\%) during the second season. The miscarriage of silica gel addition to improve soil's retention parameters, (WHC\%), (FC\%), (WP\%) and (AW\%) during the second season may attributed to the degradation of silica gel through the drying cycle in between seasons into $\mathrm{SiO}_{2}$ particles. The degradation of silica gel to $\mathrm{SiO}_{2}$ takes place when the gel loss its water content within the soil and no compensation from outer sources of water as shown in the following chemical equation.

$$
\mathrm{H}_{2} \mathrm{SiO}_{3} \text {------ } \mathrm{H}_{2} \mathrm{O}+\mathrm{SiO}_{2}
$$

The data agreed with Abedi et al. (2008) who found that a significant difference between the increase in available water content in amended sandy loam and clay soils. The addition of $4-6 \mathrm{~g} / \mathrm{kg}$ hydrogel to soil increased the available water content in sandy loam by a factor of $2.2-2.3$, whereas in clay that factor was 1.1-1.2. Similar trend showed by Bhat et al. (2009). Wael and Oswald (2015) found that the addition of hydro gel increased significantly soil water content $(\theta \mathrm{v})$ under different pressure values. The highest values of $\theta_{\mathrm{v}}$ recorded to the $4 \mathrm{~g} / \mathrm{Kg}$ soil which was the highest application rate of hydro gel-. While, untreated soil observed with the lowest values of $\left(\theta_{\mathrm{v}}\right)$. Also the addition of hydrogel increased significantly the water holding capacity, field capacity and wilting point. Also, the amount of plant available soil water (AW) increased significantly and linearly in soil with the addition of hydrogel compared with untreated soils. Dorraji et al. (2010) indicated that small doses of gel polymers efficiently increased water retention in soils of various grain size structures. Helalia et al., (1992) showed that $2.5-15 \mathrm{~g} / \mathrm{kg}$ doses of hydrogel Acryhope and Aquastore-B increased total porosity and the retention of useful water in the investigated soils. Piotr (2009) found that at smaller doses of hydrogel $(0.5,2$ and $4 \mathrm{gdm}-3)$ there were a decrease of soil retention capacity was observed as compared with the control. But with enrichment of soil with $6 \mathrm{~g}$ of hydrogel per $\mathrm{dm}^{3}$ markedly increased retention capacity of soil in the permanent wilting point. Also silica gel increased soil water capacity in the range of $\mathrm{pF}$ from 3 to 4.2 . The largest increment in retention capacity (28\%) compared with the control was obtained in the variant with $4 \mathrm{~g} \cdot \mathrm{dm}^{-3}$. hydrogel doses of 2 and $6 \mathrm{~g} \cdot \mathrm{dm}^{-3}$ increased water retention capacity in soil by $13 \%$ and $16 \%$, respectively. The largest increment of retention capacity at $\mathrm{pF} 2.2-3$ was noted for the addition of $2.0 \mathrm{~g} \cdot \mathrm{dm}^{-3}$ hydrogel (increase by $31 \%$ as compared with control). 
Table 7: Effect of Irrigation levels and silica gel treatments on available water (AW\%) during the first season and their residual effects through the second season.

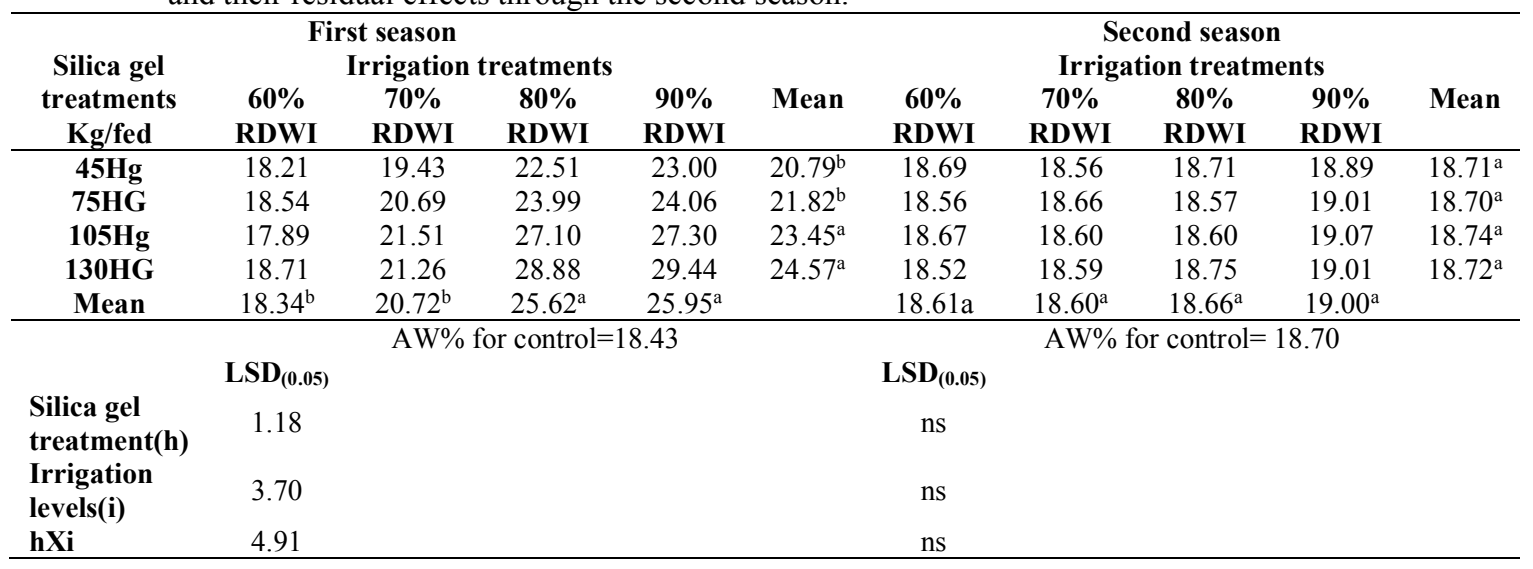

2- Effect of silica gel treatments at different irrigation levels on some physical properties of soil: a- Hydraulic conductivity of soil:-

Significant decreases in hydraulic conductivity $(\mathrm{Ks}, \mathrm{cm} / \mathrm{hr})$ were observed with the increase in the doses of silica gel to soil under different irrigation levels as shown in Table (8) .The high significant value of Ks was associated with control treatment $(0.91$ day/hr)for the first season while the lowest value $(0.72 \mathrm{day} / \mathrm{hr})$ recorded to $130 \mathrm{~kg} / \mathrm{fed}$ of silica gel treatment. The relative decrease in hydraulic conductivity of improved soil was $(20.88 \%)$ for $130 \mathrm{~kg} / \mathrm{fed}$ of silica gel treatment. Also, with respect to the second season there were insignificant differences due to the addition of silica gel treatments to soil. It worth mentioning that there was a significant reducing in Ks between the two levels of irrigation $80 \%$ RDWI and $90 \%$ RDWI where the $90 \%$ RDWI recorded the highest reducing in Ks value due to adding different levels of silica gel to soil. On the other hand, the addition of silica gel with different amounts insignificantly improved the hydraulic conductivity (Ks) of the investigated soil during the second season. The aforementioned results agreed with Wael and Oswald (2015) who attributed the decrease in the Ks values of the soil-silica gel mixture may be due to the decrease in the pore space between the soil particles and aggregates. The swelling of the hydrogel within the soil matrix was at the expense of some soil capillaries available for the water movement. Consequently, the volume of the water conducting pores decrease, the permeability of the matrix and thus the Ks decrease at low concentrations of the hydrogel (Dorraji et al., 2010; Shahid et al., 2012).

\section{b- Bulk density of soil:}

Data presented in Table (9) indicated that bulk density $\left(\mathrm{BD} \mathrm{g} / \mathrm{cm}^{3}\right)$ of the soil mixed with silica gel significantly reduced compared to the control treatment. The $130 \mathrm{~kg} /$ fed treatment ranked the minimum value of BD $\left(1.262 \mathrm{~g} / \mathrm{cm}^{3}\right)$ compared to the untreated soil which was the maximum one $\left(1.431 \mathrm{~g} / \mathrm{cm}^{3}\right)$ under all irrigation levels .on the other side there were insignificant differences in (BD) values during the second season. The relative decrease in (BD) values due to adding different rates of silica gel to soil was $11.81 \%$. Also there were significant differences in (BD) values due to different irrigation levels, where the $90 \%$ RDWI gained the lowest (BD) value $\left(1.262 \mathrm{~g} / \mathrm{cm}^{3}\right)$ at $130 \mathrm{~kg} / \mathrm{fed}$ silica gel treatment. The results in agreement with Wael and Oswald (2015) who indicated that BD of the soil mixed with hydrogel was significantly reduced compared with the control treatment. The $0.4 \%$ hydrogel treatment exhibited a minimum significant value of $\operatorname{BD}\left(1.21 \mathrm{~g} \mathrm{~cm}^{-3}\right)$ and the untreated soil observed with the maximum significant value $\left(1.51 \mathrm{~g} \mathrm{~cm}^{-3}\right)$ of BD. The hydrogel particles within the soil matrix absorb water and become larger in size. The soil particles are displaced and rearranged around the swollen particles of the silica gel. So, the soil volume increases and hence the ratio of the dry mass of the soil to its volume decreases (Luo and Polle, 2009). 
Table 8: Effect of Irrigation levels and silica gel treatments on saturated hydraulic conductivity $(\mathrm{Ks} \mathrm{cm} / \mathrm{hr})$ during the first season and their residual effects through the second season.

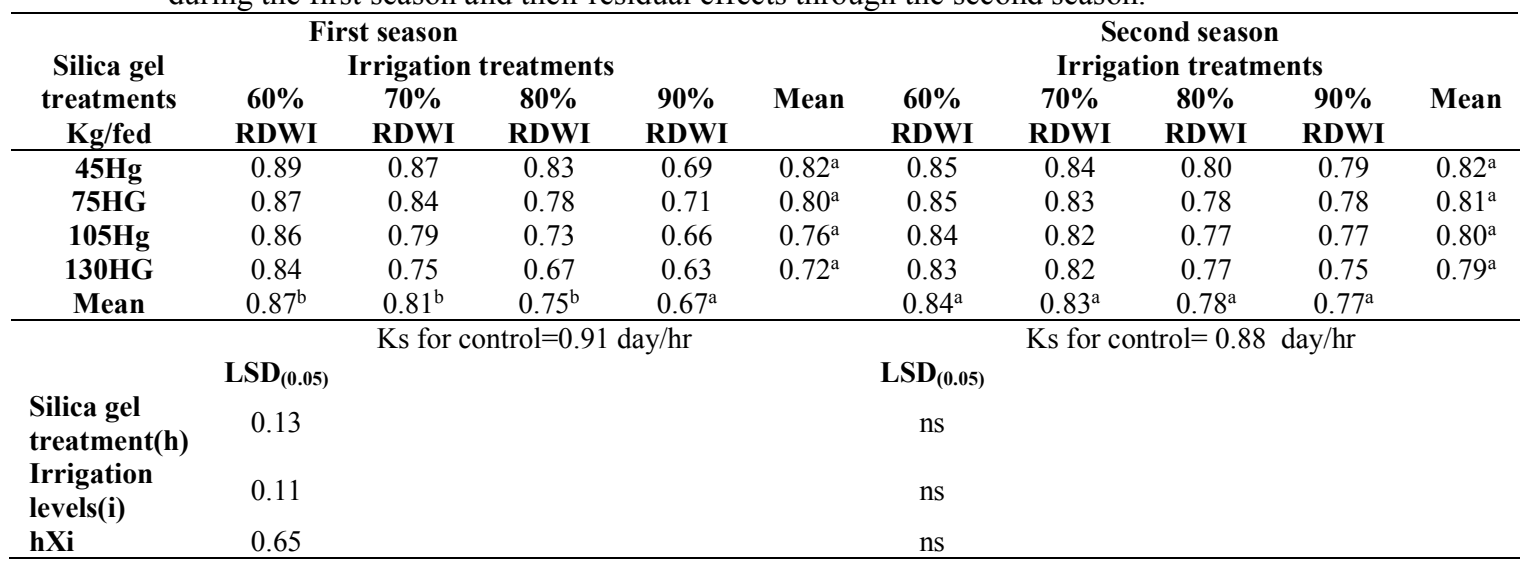

Table 9: Effect of Irrigation levels and silica gel treatments on bulk density $\left(\mathrm{BD} \mathrm{g} / \mathrm{cm}^{3}\right)$ during the first season and their residual effects through the second season.

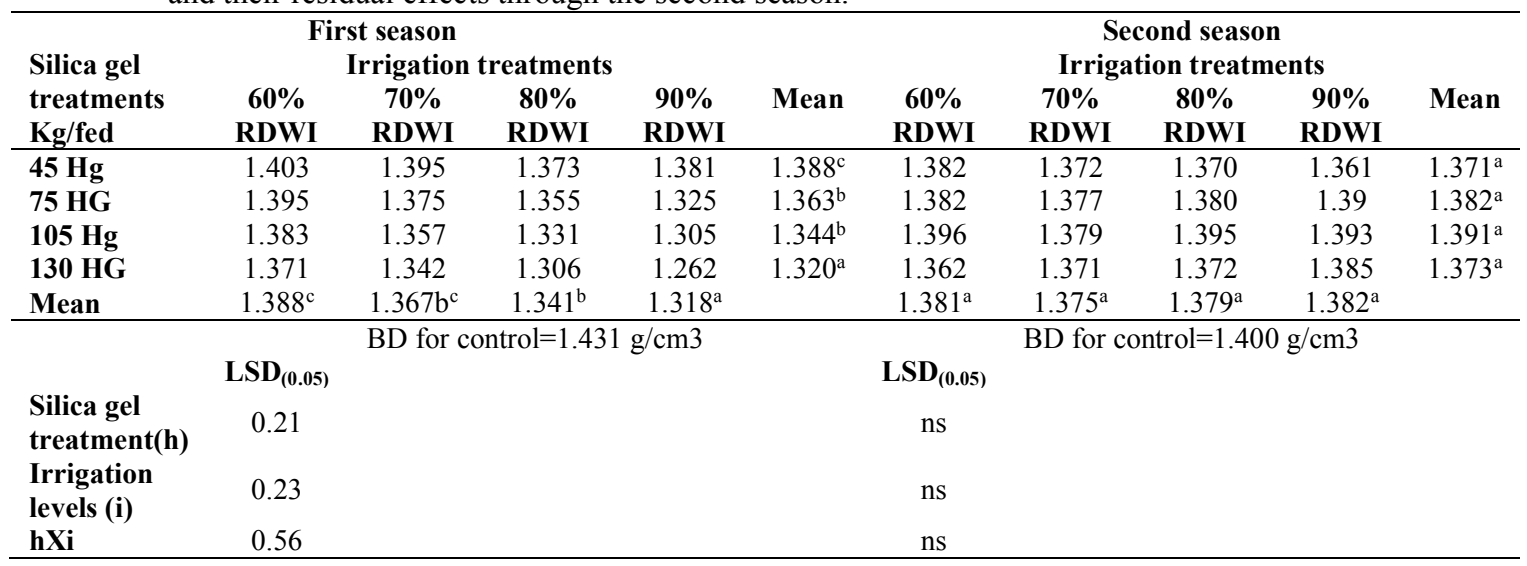

3- Effect of silica gel treatments at different irrigation levels on rice and clover crop yields and on their crop water productivity (CWP): -

a- crop yield:-

The data illustrated in Table (10) revealed that mixing the clay soil with different rate of silica gel showed high pronounced effect on the rice crop yield through the first season and insignificant for their residual effects on clover crop during the second season. The highest values of crop yield recorded for rice crop at the $130 \mathrm{~kg} /$ fed of silica gel and it was $4.10 \mathrm{~kg} / \mathrm{fed}$ and 4.29 for the irrigation levels of $80 \%$ RDWI and $90 \%$ RDWI in first season respectively. While, there is no significant differences between the $80 \%$ RDWI and $90 \%$ RDWI levels were found. On the other hand, the addition of silica gel to soil with different amounts under all levels of irrigation gave insignificantly effect to the clover crop yield during the second season. Also insignificant differences were observed between both the $80 \%$ RDWI and $90 \%$ RDWI levels with the increase in the concentration of silica gel in soil.

\section{b- Crop water productivity $\left(\mathrm{CWP} \mathrm{Kg} / \mathrm{m}^{3}\right)$ :-}

With respect to the crop water productivity $\left(\mathrm{CWP} \mathrm{Kg} / \mathrm{m}^{3}\right)$ as shown in Table (11), similar trend was observed where the addition of silica gel to soil increased significantly (CWP) to rice crop. Where the $80 \%$ RDWI and 90\%RDWI levels recorded the highest values $0.77 \mathrm{~kg} / \mathrm{m}^{3}$ and $0.73 \mathrm{~kg} / \mathrm{m}^{3}$ respectively without significant differences between them. Whereas the residual effect of silica gel was no longer effect on (CWP) for the clover crop during the second season. Similar trend was found form Wael and Oswald, (2015) who observed that seed germination was considerably higher in 0.1$0.4 \%$ hydrogel amended soils as compared to the control. Also, shoot length of grass was significantly 
higher in $0.1-0.4 \%$ hydrogel compared with control. Moreover the addition of hydrogel to soil significantly increased the fresh and dry weights of grass shoots. Also, this similar trend could be due to the prepared hydrogel improved the water storage and increased the field capacity of soil and thus the plant available water (Shahid et al., 2012). Also, the plants that grown in hydrogel, produced plants with large volume comparing with those grown in media free of hydrogel, (Abdel-Raouf, 2003).

Table 10: Effect of Irrigation levels and silica gel treatments on rice crop yield (ton/fed) during the first season and their residual effects on clover crop yield (ton/fed) through the second season.

\begin{tabular}{|c|c|c|c|c|c|c|c|c|c|c|}
\hline \multicolumn{6}{|c|}{ First season (rice crop) } & \multirow{2}{*}{\multicolumn{5}{|c|}{$\begin{array}{l}\text { Second season(clover crop) } \\
\text { Irrigation treatments }\end{array}$}} \\
\hline Silica gel & & Irrigation & ceatmen & & & & & & & \\
\hline $\begin{array}{l}\text { treatments } \\
\mathrm{Kg} / \mathrm{fed}\end{array}$ & $\begin{array}{c}60 \% \\
\text { RDWI }\end{array}$ & $\begin{array}{c}70 \% \\
\text { RDWI }\end{array}$ & $\begin{array}{c}80 \% \\
\text { RDWI }\end{array}$ & $\begin{array}{l}\text { 90\% } \\
\text { RDWI }\end{array}$ & mean & $\begin{array}{c}60 \% \\
\text { RDWI }\end{array}$ & $\begin{array}{c}70 \% \\
\text { RDWI }\end{array}$ & $\begin{array}{l}\mathbf{8 0 \%} \\
\text { RDWI }\end{array}$ & $\begin{array}{l}90 \% \\
\text { RDWI }\end{array}$ & mean \\
\hline $45 \mathrm{Hg}$ & 1.08 & 2.14 & 2.95 & 3.21 & $2.35^{\mathrm{c}}$ & 0.75 & 0.90 & 1.08 & 1.38 & $1.03^{\mathrm{a}}$ \\
\hline $75 \mathrm{HG}$ & 1.90 & 2.58 & 3.31 & 3.70 & $2.87^{\mathrm{b}}$ & 0.76 & 0.92 & 1.08 & 1.54 & $1.08^{\mathrm{a}}$ \\
\hline $105 \mathrm{Hg}$ & 2.59 & 2.89 & 3.72 & 4.02 & $3.31^{\mathrm{a}}$ & 0.89 & 1.10 & 1.31 & 1.54 & $1.21^{\mathrm{a}}$ \\
\hline $130 \mathrm{HG}$ & 2.70 & 3.02 & 4.10 & 4.29 & $3.61^{\mathrm{a}}$ & 0.88 & 1.10 & 1.29 & 1.59 & $1.22^{\mathrm{a}}$ \\
\hline \multirow[t]{3}{*}{ Mean } & $2.07^{\mathrm{c}}$ & $2.66^{\mathrm{b}}$ & $3.59^{\mathrm{a}}$ & $3.81^{\mathrm{a}}$ & & $0.82^{\mathrm{c}}$ & $1.01^{\mathrm{b}}$ & $1.19^{\mathrm{b}}$ & $1.51^{\mathrm{a}}$ & \\
\hline & \multicolumn{5}{|c|}{ Yield for control $=4.28$ ton $/$ fed } & \multicolumn{5}{|c|}{ Yield for control=2.11 ton $/$ fed } \\
\hline & $\mathbf{L S D}_{(0.05)}$ & & & & & $\operatorname{LSD}_{(0.05)}$ & & & & \\
\hline $\begin{array}{c}\text { Silica gel } \\
\text { treatment(h) }\end{array}$ & 0.39 & & & & & ns & & & & \\
\hline $\begin{array}{c}\text { Irrigation } \\
\text { levels(i) }\end{array}$ & 0.83 & & & & & 0.25 & & & & \\
\hline $\mathbf{h X i}$ & 1.11 & & & & & ns & & & & \\
\hline
\end{tabular}

Table 11: Effect of Irrigation levels and silica gel treatments on crop water productivity $\left(\mathrm{CWP} \mathrm{kg} / \mathrm{m}^{3}\right)$ for rice crop during the first season and their residual effects on $\left(\mathrm{CWP} \mathrm{kg} / \mathrm{m}^{3}\right)$ for clover crop through the second season.

\begin{tabular}{|c|c|c|c|c|c|c|c|c|c|c|}
\hline $\begin{array}{l}\text { Silica gel } \\
\text { treatments } \\
\text { Kg/fed }\end{array}$ & \multicolumn{4}{|c|}{ First season } & Mean & \multicolumn{5}{|c|}{$\begin{array}{c}\text { Second season } \\
\text { Irrigation treatments }\end{array}$} \\
\hline $75 \mathrm{HG}$ & 0.49 & 0.56 & 0.64 & 0.63 & $0.58^{\mathrm{b}}$ & 0.49 & 0.51 & 0.52 & 0.66 & $0.55^{\mathrm{a}}$ \\
\hline $105 \mathrm{Hg}$ & 0.66 & 0.64 & 0.72 & 0.69 & $0.68^{\mathrm{a}}$ & 0.57 & 0.61 & 0.63 & 0.66 & $0.62^{\mathrm{a}}$ \\
\hline $130 \mathrm{HG}$ & 0.69 & 0.66 & 0.77 & 0.73 & $0.71^{\mathrm{a}}$ & 0.56 & 0.60 & 0.62 & 0.68 & $0.62^{\mathrm{a}}$ \\
\hline \multirow{4}{*}{$\begin{array}{l}\text { Silica gel } \\
\text { treatment(h) } \\
\text { Irrigation } \\
\text { levels(i) } \\
\text { hXi }\end{array}$} & \multicolumn{5}{|c|}{$\left(\mathrm{CWP} \mathrm{kg} / \mathrm{m}^{3}\right)$ for control $=0.69$} & \multicolumn{5}{|c|}{$\left(\mathrm{CWP} \mathrm{kg} / \mathrm{m}^{3}\right)$ for control $=0.76$} \\
\hline & \multicolumn{4}{|l|}{$\operatorname{LSD}_{(0.05)}$} & & \multicolumn{5}{|l|}{$\operatorname{LSD}_{(0.05)}$} \\
\hline & 0.07 & \multicolumn{9}{|c|}{ ns } \\
\hline & 0.08 & \multicolumn{9}{|c|}{0.05} \\
\hline
\end{tabular}

\section{Conclusion}

The best values obtained were existed under the high rate of silica gel of $130 \mathrm{~kg} / \mathrm{fed}$ which was accompanied with $80 \%$ RDWI; on the other hand all treatments of silica gel at $60 \%$ RDWI level gave the lowest values for soil water retention parameters. Generally the values of water holding capacity (WHC\%), field capacity (FC\%), wilting point (WP\%) and available water (AW\%) were improved as a result of silica gel addition to the soil. Also mixing silica gel with the soil under investigation enhanced both of hydraulic conductivity $\left(\mathrm{Ks} \mathrm{cm} / \mathrm{hr}\right.$ ) and bulk density $\left(\mathrm{BD} \mathrm{gm} / \mathrm{cm}^{3}\right)$ especially at 130 $\mathrm{kg} /$ fed treatment. The best treatment was at $80 \%$ RDWI level for $130 \mathrm{~kg} / \mathrm{fed}$ of silica gel during the first season for both rice yield and its crop water productivity (CWP). Also there was insignificant impact for the residual effect of silica gel during the second season for clover crop. From the after mentioned data it could be concluded that using of $130 \mathrm{~kg} / \mathrm{fed}$ of silica gel as soil amendment are usable to save $20 \%$ of irrigation water in rice and be recommended to adding the gel every season due to the degradation of silica gel in between seasons within the soil which led to decrease the holding water properties. 


\section{Acknowledgment:}

The authors wish to express their sincere gratitude and appreciation to the Community Seed Production, Agronomy Research Institute and Dept. of Physics and Chemistry of Soil, Soils, Water and Environ. Res. Inst., Agric. Res. Center (ARC), Giza, Egypt, for introducing all facilities needed to accomplish this study.

\section{References}

Abdel-Raouf, A.M. and R.M. Samira, 2003. Improving Soil Physical Properties and its Effect on Acacia tortilis Seedlings Growth under Field Conditions. Asian Journal of Plant Sciences, 2(11): 861-868.

Abedi Koupai, J., S.S. Eslamian, and J. Asadkazemi, 2008. Enhancing the available water content in unsaturated soil zone using hydrogel, to improve plant growth indices. Jour. Ecohydro and Hydrobio., 8: 67-75.

Abrisham, E., 2015. Investigation of super absorbent polymer and amendment effect on soil characteristics and establishment of plant cover in arid region. Ph.D. Thesis, Agriculture and natural resource college, University of Tehran, Tehran, Iran. $172 \mathrm{p}$.

Alireza, S., H. R. Fallahi, G. Zamani, S. Nakhaie, M. Aghhavani-Shajari and A. Amirizadeh 2016. Impact of Super Absorbent Polymer and Irrigation Management on Seed and Essential Oil Yields of Cumin Journal of Medicinal Plants and By-products (2016) 2: 145-152.

Aly, E.M., M.T.E. Wafaa, and H.Y. Gehan, 2016. Peanut (Arachis hypogaea L.) Response to Different Levels of Irrigation Stress and Synthetic Soil Amendments Egypt. J. Soil Sci. Vol.56, No. 2,351-371.

ARC: Agriculture Research Center of Agriculture Ministry, Egypt, 2013.Recommendations for Egyptian rice cultivation and production. Bulletin 408; 2013. Published by ARC; Giza, Egypt.

Bal, W., H. Zhang, L.Y. Wu, and J. Song, 2010. Effects of super- absorbent polymers on the physical and chemical properties of soil following different wetting and drying cycles. Jour. Soil use and manage. 26: 253-260.

Bhat, N.R., M.K. Suleiman, H. Al-Menaie, E.H. Al-Ali, L. Al-Mulla, A. Christopher, V.S. Lekha, S.I. Ali, and P. George, 2009. Polyacrylamide polymer and salinity effects on water requirement of Conocarpus lancifolius and selected properties of sandy loam soil. European Journal of Scientific Research 25, 549-558.

Black, C.A., 1982. Methods of Soil Analysis. Soil Sci. Soc. of America, Inc. Pub. Matison Wisconsin, USA

Chen, Y.N., W.H. Li, H.H. Zhou, Y.P. Chen, X.M. Hao, A.H. Fu,. and X. Ma, 2014. Analysis of water use strategies of the desert riparian forest plant community in inland rivers of two arid regions in north western Chin. Jour. Biogeosci Discuss. 11: 14819-14856.

Chirino, E., A. Vilagrosa and V. Ramón Vallejo, 2011. Using hydrogel and clay to improve the water status of seedlings for dry-land restoration Plant Soil (2011) 344:99-110 DOI 10.1007/s11104011-0730-1

Cottien, A., M. Verloo, L. Kieken, G. Velghe and R. Comerlynch, 1982. "Chemical analysis of plants and soils". Fac. Agric., State Univ., Gent, Belgium.

Dorraji, S.S., A. Golchin and S. Ahmadi, 2010. The effects of hydrophilic polymer and soil salinity on corn growth in sandy and loamy soils. Clean-Soil Air Water, 38: 584-591.

Egyptian Ministry of Irrigation and Water Resources, 2018. Article at Ahram Journal entitled with: Reducing rice cultivation in Egypt: A controversy - Economy - Business - Ahram Online, Editing by Mona El-Fiqi, Thursday 1 Mar 2018 website http://english.ahram.org.eg/News/29196 http://english.ahram.org.eg/News/291961.aspx.

Ekebafe, L.O., D.E. Ogbeifun, and F.E. Okieimen, 2011. Polymer applications in agriculture. Jour. Biokemistri. 23: 81-89.

Evonik Industries, 2014. Water and nutrients for improved plant growth. Website is :http:// http://www.creasorb.com/product/creasorb/en/products/stockos.

FAO, Food Agriculture Organization of United Nations, Rome, 2005. Fertilizer use by crop in Egypt. Land and Plant Nutrition Management. Land and Water Development Division. Bulletin Published by FAO service, Rom.1st version chap6. pp: 28. 
Gee, G.W., and J.W. Bauder, 1986. Particle Size Analysis. In: Method of Soil Analysis, Part I (ed.A.Klute) ,pp 383-341 American Society of Agronomy, Madison.WI.

Greenwood, N.N. and A. Earnshaw, 1997. Chemistry of the Elements (2 ${ }^{\text {nd }}$ ed.). ButterworthHeinemann. ISBN 978-0-08-037941- 8.

Helalia A.M., S. EL-Amir, M.E. Shawky, 1992. Effect of Acryhope and Aquastore polymers on water regime and porosity in sandy soil. Intern. Agrophys., 6: 19-25.

Jackson, M.L., 1973. Soil Chemical Analysis. Prentice-Hall of India Pvt. Ltd., New Delhi, India, pp. 38-204.

Klute, A., 1986. Water Retention: Laboratory Methods. Part 1. Physical and Mineralogical Methods. In: "Methods of Soil Analysis", (Ed.): Klute, A.. Seconds edition. Agronomy No.9. America Society of Agronomy, Inc. Soil Science Society of America, Madison, Wisconsin. USA.

Krzysztof Lejcus; Michał S'pitalniak and Jolanta Da browska, 2018. Swelling Behaviour of Superabsorbent Polymers for Soil Amendment under Different Loads. Polymers Journal 2018, 10, 271; doi:10.3390/polym10030271

Li, Y.F., X.Z. Li, L.C. Zhou, X.X. Zhu, and B.N. Li, 2004. Study on the synthesis and application of salt-resisting polymer hydrogels. Jour. Polymers for Advanced Technolo., 15: 3438.

Liliana, S.C. and M. Alexander and G. Chalapud, 2017. Natural fibers for hydrogels production and their applications in agriculture. Acta Agron. 66 (4) p 495-505 ISSN 0120-2812 | e-ISSN 23230118.

Luo, Z. and A. Polle, 2009. Wood composition and energy content in a poplar short rotation plantation on fertilized agricultural land in a future $\mathrm{CO}_{2}$ atmosphere. Jour. Global Change Biolo., 15: 38-47.

Michael, A.M., 1978. Irrigation theory and practices. Vikas Publishing House PUTLTD New Delhi, Bombay.

Montazer, A., 2008. Study the effect of stockosorb super absorption polymer on the flow advance time and infiltration parameters in furrow irrigation. Jour. Water and Soil. 22: 341-356. (In Persian).

Murphy, J. and P. Riley, 1962. A modified single solution method for the determination of phosphate in natural waters. Anal. Chim. Acta 27:31-6.

Page, A.L., 1982. Methods of soil analysis" II chemical and Microbiological properties. (Ed.2) soil. Sci. Am. Inc., Madison, W.I.

Piotr, L., 2009. The effect of hydrogel additives on the water retention curve of sandy soil from forest nursery in Julinek. Journal of Water and land Evelopment J. Water Land Dev. No. 13a,: 239247.

Polite, E., M. Karuca, H. Demire, and N. Onus, 2004. Use of natural Zeolite (clinoptilolite) in agriculture. Jour. Fruit and Ornamental Plant Res. 12: 183-189.

Widiastuti, N., H. Wu, M. Ang, and D.K. Zhang, 2008. The potential application of natural Zeolite for grey water treatment. Jour. Desalie, 218: 271- 280.

Rahimizadeh, A., J. Farzadmehr, A. A. Rostagi, and A.A. Ramezani Gask, 2011. Comparison of effects of planting Haloxylon spp. And Atriplex spp. on the characteristics of vegetation cover and rangelands soil (A case study: Salemabad, Sarbishe, Iran). J. Renewable Natural Resources Res., 1: 1-13.

Shahid, S.A., A. Qidwai, F. Anwar, I. Ullah and U. Rashid, 2012. Improvement in the water retention characteristics of sandy loam soil using a newly synthesized poly (acrylamide-co-acrylic acid)/AlZnFe $\mathrm{O}_{4}$ superabsorbent hydrogel nanocomposite material. Molecules, 17:9397-9412.

Sharifan, H., P. Mokhtari and A. Hezarjaribi, 2013. The effect of super absorbent A200 on the Infiltration Parameters Kostiakov-Lewis Equation in Furrow Irrigation. J. Water and Soil, 27: 205-212.

Thakur, A.K., R.K. Mohanty, D.U. Patil, and A. Kumar, 2014. Impact of water management on yield and water productivity with system of rice intensification (SRI) and conventional transplanting system in rice. Paddy Water Environ., 12, 413-424.

USSL, United States Salinity Laboratory Staff, 1969. Diagnosis and Improvement of Saline and Alkaline Soils. Agriculture. Handbook $2^{\text {nd }}$. ed. No. 60, Us, Dep. of Agriculture. 
Wael, M. Nada and B. Oswald, 2015. Characterization and Impact of Newly Synthesized Superabsorbent hydogel Nanocomposite on Water Retention Characteristics of Sandy Soil and Grass Seedling Growth .International Journal of Soil Science, 10(4):153-165.

Watanabe F.S and S.R. Olsen, 1965. Test of an ascorbic acid method for determining phosphorus in water and NaHCO3 extracts from soil. Soil Sci. Soc. Am. Proc. J., 29: 677- 678.

Widiastuti, N., Wu, Hongwei; Ang, Ha and Zhang, Dongke, 2008. The potential application of natural zeolite for greywater treatment. Desalination Journal, 218(1): 271-280.

Wu, L., M. Liu, and R. Liang, 2008. Preparation and properties of a double-coated slow-release NPK compound fertilizer with superabsorbent and water-retention. J. Biores Techno., 99: 547-554.

Wu, Q., Q. Zhang, and B. Zhang, 2012. Influence of super-absorbent polymer on the growth rate of gas hydrate. Jour. Safety Sci., 50: 865-868.

Yousefian, M., M. Jafari, A.Tavili, H. Arzani and Z. Jafarian, 2018. The effects of superabsorbent polymer on Atriplex lentiformis growth and soil characteristics under drought stress (case study: Desert research Station, Semnan, Iran). Journal of Rangeland Science, 8(1):65-76.

Zangooei, N., Sh., H. Emami, A.R. Astaraei, and A.R. Yari, 2013. Effects of stockosorb hydrogel and irrigation intervals on some soil physical properties and growth of Haloxylon seedling. Jour. Soil Manage Sustainable, 3: 167-182.

Zohurian-Mehr, M.J. and K. Kabiri, 2008. Superabsorbent polymer materials: A review. Jour. Polymer. 17: 451-477. 